Ethiopian Journal of Environmental Studies \& Management 10(3): 286 - 298, 2017.

ISSN:1998-0507

Submitted: November 29, 2016

doi: https://dx.doi.org/10.4314/ejesm.v10i3.2

Accepted: April 04, 2017

\title{
OCCURRENCE AND DISTRIBUTION OF HEAVY METALS IN INDOOR SETTLED PARTICLES IN LAGOS METROPOLIS, NIGERIA
}

\author{
${ }^{*}$ OSUALA, F. I., ${ }^{1}$ OTITOLOJU, A.A. ${ }^{1}$ AND IGWO-EZIKPE, M.N. ${ }^{2}$ \\ ${ }^{1}$ Department of Zoology, Faculty of Science, University of Lagos, P.M.B. 101017, Lagos, \\ Nigeria \\ ${ }^{2}$ Department of Biochemistry, Faculty of Basic Medical sciences, College of Medicine, \\ University of Lagos, P.M.B. 12003, Lagos, Nigeria
}

\begin{abstract}
The increased application of technology, industrialization and growing population has resulted in the emission of wastes such as heavy metals that pollute the environment. The occurrence and distribution of heavy metals such as cadmium (Cd), copper (Cu), chromium $(\mathrm{Cr})$, iron ( $\mathrm{Fe})$, manganese ( $\mathrm{Mn})$, lead ( $\mathrm{Pb})$, nickel (Ni) and zinc ( $\mathrm{Zn})$ in settled particles (indoor) collected from selected residential in Lagos metropolis over a two-year period (February, 2007 - July, 2008) was therefore investigated. The measurements of heavy metals contents were performed using Atomic Absorption Spectroscopy (AAS). The results showed widespread heavy metals contamination especially Fe and $\mathrm{Zn}$, which were present as the highest concentration while $C d$ was the lowest in the settled particles (dust). The order of occurrence of heavy metals in settled particles (dust) collected indoor in 2007 and 2008 respectively were as follows, $\mathrm{Fe}>\mathrm{Zn}>\mathrm{Pb}>\mathrm{Cu}>\mathrm{Cr}>\mathrm{Mn}>\mathrm{Ni}>\mathrm{Cd}$ and $\mathrm{Fe}>\mathrm{Zn}>\mathrm{Mn}$ $>\mathrm{Pb}>\mathrm{Cr}>\mathrm{Cu}>\mathrm{Ni}>\mathrm{Cd}$. The outcome of this study implied that dust represent major source of heavy metals around dwelling places in the Lagos metropolis and therefore should be monitored. Additionally, data from this study could stand as a reference point for subsequent monitoring.
\end{abstract}

Key Words: Heavy metals, Settled particle, Indoor, Dust, Lagos metropolis, Dwelling

\section{Introduction}

The application of technology to explore and exploit natural resources inadvertently resulted in the release of varied types and amounts of industrial wastes into the environment. These industrial wastes are complex admixtures of several classes of pollutant such as hydrocarbons and heavy metals (Oyewo and Don-Pedro, 2002). Rapid economic growth via industrialization has contributed immensely to the heavy metal load in the environment (Abdul, 2011; Chin et al., 2012). Heavy metals are toxic at relatively low concentrations (Falusi and Olanipekun, 2007; Raymond and Felix, 2011), bioaccumulate (Chukwu, 1991; Otitoloju and DonPedro, 2002 and 2004) and persist in the environment long after the source of emission has been removed thus an important sources of pollution (DeVagi and Arfiziah, 2009). Anthropogenic activities (mining and industrialization)

*Corresponding Author: Osuala, F.I. 
have increased the natural heavy metals constituents of the earth's crust (Adriano, 2001; Mohamed and Elsayed, 2007). Heavy metals in the atmosphere come in contact with air particles such as settled particles (dust) (Shinggu et al., 2007) that pollute the environment and penetrate living cells resulting in a number of chronic toxic effect (Kan, 2011; Sham et al., 2011 and Umme et al., 2011). Classical cases of heavy metal toxicities include Minamata (Kurland, 1960), Niigata disease (Gary et al., 2007), "Quiet baby" syndrome caused by mercury (Al - Damluji, 1976), Itai - Itai caused by cadmium (Jun-ichi, 2006). These have been known to contribute immersely to decline in human population. At present in Nigeria, there is relatively scanty documented data available on the occurrence and distribution of heavy metals in settled particles indoor environment within dwelling places in the Lagos metropolis. Settled particles are significant environmental media from which information about the concentration, distribution and fate of contaminants present in the surface environment could be obtained. Higher concentrations of $\mathrm{Pb}$, $\mathrm{Zn}, \mathrm{Cr}, \mathrm{Ni}, \mathrm{Cd}$ and $\mathrm{Cu}$ have been detected in urban households dust (Anna et al., 2008; Dan'Azumi and Bichi, 2010) a situation of growing concern. Moreover high toxicity even at low concentrations has been observed (Marcovecchio et al., 2007). This is further enhanced because of daily exposure of individuals who spend significant amount of time in houses, day care centres, schools, offices, markets and dwelling places. It is for this reason that settled particles were used for monitoring heavy metal pollution in the environment. This study was designed to provide information on heavy metals occurrence and distribution patterns in settled particles sources in selected areas of the Lagos metropolis indoors precisely in places where people spend considerable period of time. This will provide documented environmental data on heavy metals background as a fill-up on environmental studies.

\section{Materials and Methods Description of Study Area}

The Lagos metropolis lies within the South-Western Nigeria, located on longitude $3^{\circ} 10^{\prime} 36^{\prime \prime}-3^{\circ} 35^{\prime \prime} 08^{\prime \prime} \mathrm{E}$ and latitude $6^{\circ} 20^{\prime} 32^{\prime \prime}-6^{\circ} 40^{\prime} 15^{\prime \prime} \mathrm{N}$. It occupies an area of about 3,475.1 square kilometres, with an estimated population of 15.7 million inhabitants (Oyegoke et al., 2012). About $80 \%$ of this population resides in metropolitan Lagos making the state; the most urbanized in Nigeria. Lagos metropolis is a place of high commercial activities thus experience high traffic density comparatively. The Lagos metropolis was selected on the basis of traffic load, population density and anthropogenic activities (fig.1). Temperature ranges from $26-33^{\circ} \mathrm{C}$.

\section{Sample Locations}

The Lagos metropolis was divided into four zones based on population density per square kilometer. The zones were areas of low density (Ikoyi/Akoka Campus), medium density (Isolo), and high density (Ajegunle). Within each zone, three houses, one market place, one school premise and one office sampling stations were established making a total of six stations per zone. These stations were randomly picked per zone. The global Positioning system was used to measure the Longitude and Latitude of the sampling locations (fig. 1 and table $1)$. 


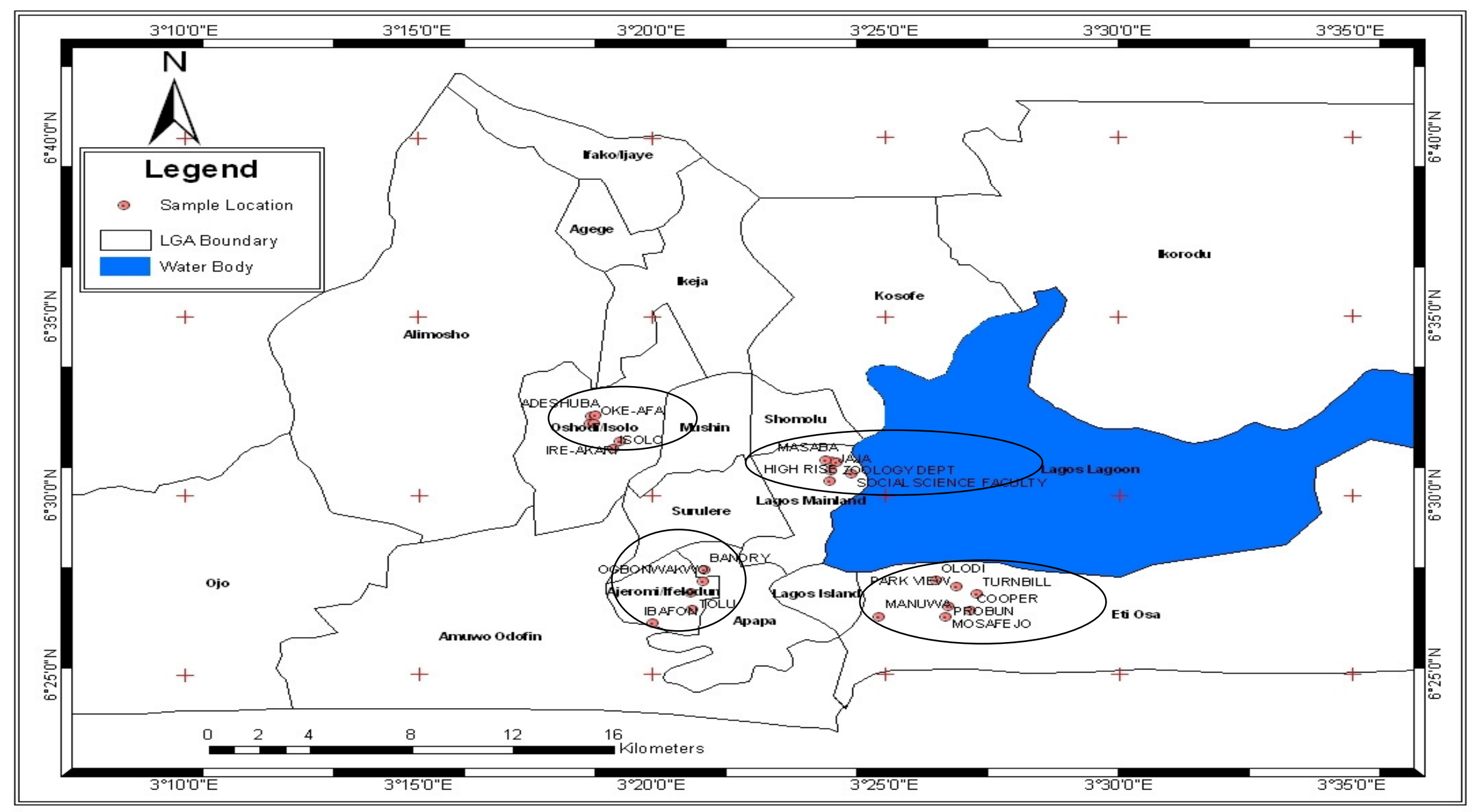

Figure 1: Map of Lagos metropolis showing the sampled zone 
Table 1: Sampling stations and their coordinates

\begin{tabular}{|c|c|c|c|c|}
\hline ZONES & LOCATION/ DENSITY & SAMPLING STATION & COORDINATES & LOCATION \\
\hline \multirow[t]{6}{*}{1} & AJEGUNLE (HIGH ) & 1 & 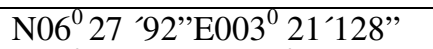 & BOUNDARY \\
\hline & & 2 & N06 $27^{\circ} 631^{\prime \prime E} 003^{0} 26^{\prime} 099^{\prime \prime}$ & OLODI \\
\hline & & 3 & N06 $26^{\prime} 431^{\prime \prime E} 003^{0} 20^{\prime} 013^{\prime \prime}$ & IBAFON \\
\hline & & 4 & N06ㅇ $27^{\prime 2} 276^{\prime \prime E} 003^{0} 20^{\prime} 828^{\prime \prime}$ & NOSAMU \\
\hline & & 5 & N06 $27^{\prime \prime 597 ” E 0030 ~ 21 ' 107 ” ' ~}$ & OGBONWAKWO \\
\hline & & 6 & N06 26 '822”E003 20'873" & TOLU \\
\hline \multirow[t]{6}{*}{ II } & AKOKA/UNILAG (LOW) & 7 & N06 $333^{\circ} 730^{\prime \prime E} 003^{0} 24^{\prime} 185^{\prime \prime}$ & SOCIAL SCIENCE \\
\hline & & 8 & $\mathrm{~N}^{\prime} 6^{0} 30^{\prime} 57.8^{\prime \prime} \mathrm{E} 003^{0} 23^{\prime} 50.6^{\prime \prime}$ & $\begin{array}{l}\text { ZOOLOGY } \\
\text { DEARTMENT }\end{array}$ \\
\hline & & 9 & N06 ${ }^{0} 30^{\prime} 55.9^{\prime \prime} \mathrm{E} 003^{0} 23^{\prime} 57.7^{\prime \prime}$ & STAFF SCHOOL \\
\hline & & 10 & N06 $31^{\prime} 58.0^{\prime \prime}=003^{0} 23^{\prime} 51.7^{\prime \prime}$ & JAJA \\
\hline & & 11 & N06 $31^{\prime} 00.3^{\prime \prime E} 003^{0} 23^{\prime} 43.5^{\prime \prime}$ & MASABA \\
\hline & & 12 & $\mathrm{~N}^{\circ} 6^{0} 30^{\prime} 24.5^{\prime \prime} \mathrm{E} 003^{0} 23^{\prime} 49.1 "$ & HIGH RISE \\
\hline \multirow[t]{6}{*}{ III } & IKOYI (LOW) & 13 & N06 ${ }^{0} 26^{\prime} 899^{\prime \prime E} 003^{0} 26^{\prime} 340^{\prime \prime}$ & PROBUN \\
\hline & & 14 & N06 ${ }^{0} 26^{\prime} 616^{\prime \prime E} 003^{0} 24^{\prime} 865^{\prime \prime}$ & MANUWA \\
\hline & & 15 & N06 $26^{\prime} 606^{\prime \prime E} 003^{0} 26^{\prime} 291^{\prime \prime}$ & MOSAFEJO \\
\hline & & 16 & N06 $27^{0} 254^{\prime \prime E} 003^{0} 26^{\prime} 956^{\prime \prime}$ & TURNBILL \\
\hline & & 17 & N06 $27^{\circ} 451^{\prime \prime E} 003^{0} 26^{\prime} 521^{\prime \prime}$ & PARK VIEW \\
\hline & & 18 & N06" $26^{\prime \prime} 776^{\prime \prime E} 003^{0} 26^{\prime} 820^{\prime \prime}$ & COOPER \\
\hline \multirow[t]{6}{*}{ IV } & ISOLO (MEDIUM) & 19 & N06 $31^{\prime} 31^{\prime \prime E} 003^{0} 19^{\prime} 18^{\prime \prime}$ & ISOLO \\
\hline & & 20 & N0632 '12.7'E003 $18^{\prime} 41.9 ”$ & PROSPERITY \\
\hline & & 21 & N06 $31^{\prime} 31.8^{\prime \prime E} 003^{0} 19^{\prime} 19.6 "$ & IRE-AKARI \\
\hline & & 22 & N06 32 '14.4"E003 ${ }^{0} 18^{\prime} 48.1 "$ & ADESHUBA \\
\hline & & 23 & N06 $32^{\prime} 00.8^{\prime \prime E} 003^{0} 18^{\prime} 41.7^{\prime \prime}$ & OLUADEBAYO \\
\hline & & 24 & N06 $32^{\prime} 01.4^{\prime \prime}=003^{0} 18^{\prime} 46.3^{\prime \prime}$ & OKE-AFA \\
\hline
\end{tabular}

\section{Sampling Schedule}

The sampling period was between two years (February, 2007 to July, 2008); this was to reflect the two major seasons (dry and rainy seasons) in Nigeria. The sampling schedules were as follows:

Dry season sampling, 17 - 23 February 2007

Wet season sampling, 16 - 22 July 2007

Dry season sampling, 17 - 23 February 2008

Wet season sampling, 16 - 22 July 2008 Collection of Settled Particles (Dust) Samples

Settled particles samples from the twenty four (24) sampling stations (indoor) were collected in triplicates using a new broom to sweep and a clean plastic dust pan to pack the samples. The collected settled particles were transferred into polyethene bags and labeled. A subsample of the settled particles was collected from the original sample and transferred into polyethene bags and labeled. All samples were stored in a dry place until analyzed.

Digestion of Samples for Atomic Absorption Spectrophotometry (AAS)

Sieved dust samples (1g) were digested according to the method adopted by Agemian and Chau (1976) as well as Bryan and Langston (1992).

Determination of Heavy Metals in Samples (Settled particles)

All digestates obtained from settled particles were filtered through Whatman No.1 filter paper and made up to the mark in appropriate volumetric flasks $\left(50 \mathrm{~cm}^{3}\right.$ 
for water samples and $100 \mathrm{~cm}^{3}$ for settled particles samples). The heavy metal content were then determined using AAS (Perkin Elmer, Analyst 200 AAS). The absorbances of test samples were compared to absorbance of standard solutions using an Alpha-4 Cathode on AAS.

\section{Statistical Analysis}

Results were expressed as Mean \pm SEM. Statistical significant $(\mathrm{P}<0.05)$ difference based on Duncan multiple range test at 0.05 was determined using one way analysis of variance (ANOVA). All data were analyzed using Statistical Package for the Social Science 16.0 for windows (SPSS 16.0 Inc., Chicago, U.S.A).

\section{Quality Assurance}

The reliability of the results was confirmed by taking appropriate quality assurance and procedure. The containers, brooms and plastic packers used were properly cleaned and sterilized. Reagent blank determinations were used to correct the instrument readings and repeated calibration of analytical equipment was done. Deionised water was used throughout the study to prevent volatile species from contaminating the sample solution. Samples were properly preserved and labelled to avoid mix up. All samples were carefully handled to avoid contamination.

\section{Results}

Indoor heavy metals analysis of samples collected from the four different zones in 2007 and 2008, showed that Cd, $\mathrm{Cr}, \mathrm{Cu}, \mathrm{Fe}, \mathrm{Mn}, \mathrm{Ni}, \mathrm{Pb}$ and $\mathrm{Zn}$ were detected.
In 2007 indoor settled particles analysis (fig. 2a), showed that zones $2\left(1.12 \mu \mathrm{gg}^{-}\right.$ $\left.{ }^{1}\right)$ and $3\left(0.11 \mu \mathrm{gg}^{-1}\right)$ had the highest and lowest level of $\mathrm{Cd}$ significantly $(\mathrm{P}<0.05)$ different from the other zones respectively. The highest level of $\mathrm{Cu}$ (zone 2; 122.84 $\mathrm{gg}^{-1}$ ) and $\mathrm{Zn}$ (zone 1; $\left.182.01 \mathrm{ggg}^{-1}\right)$ were significantly $(\mathrm{P}<0.05)$ different amongst the zones whereas the lowest levels were detected in zone 3 (18.04; $122.40 \mathrm{\mu gg}^{-1}$ ) correspondingly. Zones 3 and 1 had the highest and lowest $\mathrm{Cr}$ concentrations of $\left(75.04 \mu \mathrm{gg}^{-1}\right)$ and (30.37 $\mu^{-1}$ ) respectively significantly $(\mathrm{P}<0.05)$ different compared to the other zones. Ni level was highest in zone 2 (43.10 $\left.\mu \mathrm{gg}^{-1}\right) \quad$ significantly $\quad(\mathrm{P}<0.05)$ different from the other zones whereas, it was lowest in zone $3\left(12.13 \mu \mathrm{gg}^{-1}\right)$ not significantly $\quad(\mathrm{P}>0.05)$ different from zone 1 and $4 . \mathrm{Pb}$ levels was highest in zone 2 (133.63 $\left.\mu g^{-1}\right)$, significantly $(\mathrm{P}<0.05)$ different from the other zones whereas, the lowest level was detected in zone 3 (92.06 $\left.\mu^{-1}\right)$ but was not significantly $(\mathrm{P}>0.05)$ different from zone 1 but different from zone 4. In addition, Fe level was significantly $(\mathrm{P}<0.05)$ higher in zone $2\left(3076.01 \mathrm{\mu gg}^{-}\right.$ $\left.{ }^{1}\right)$ than the other zones while it lowest in zone 4 (2719.19 $\mu^{-1}$ ) not significantly $(\mathrm{P}>0.05)$ different from zone 1. Mn was highest in zone $2\left(51.45{\mu g g^{-1}}^{-1}\right.$ which not significant $(\mathrm{P}>0.05)$ different between zone 1 and 3 . The indoor prevalence in 2007 was $\mathrm{Fe}$ $>\mathrm{Zn}>\mathrm{Pb}>\mathrm{Cu}>\mathrm{Cr}>\mathrm{Mn}>\mathrm{Ni}>\mathrm{Cd}$ while in terms of occurrence amongst the zones, the order was zone $2>3>1>4$ (fig. $2 a$ ). 


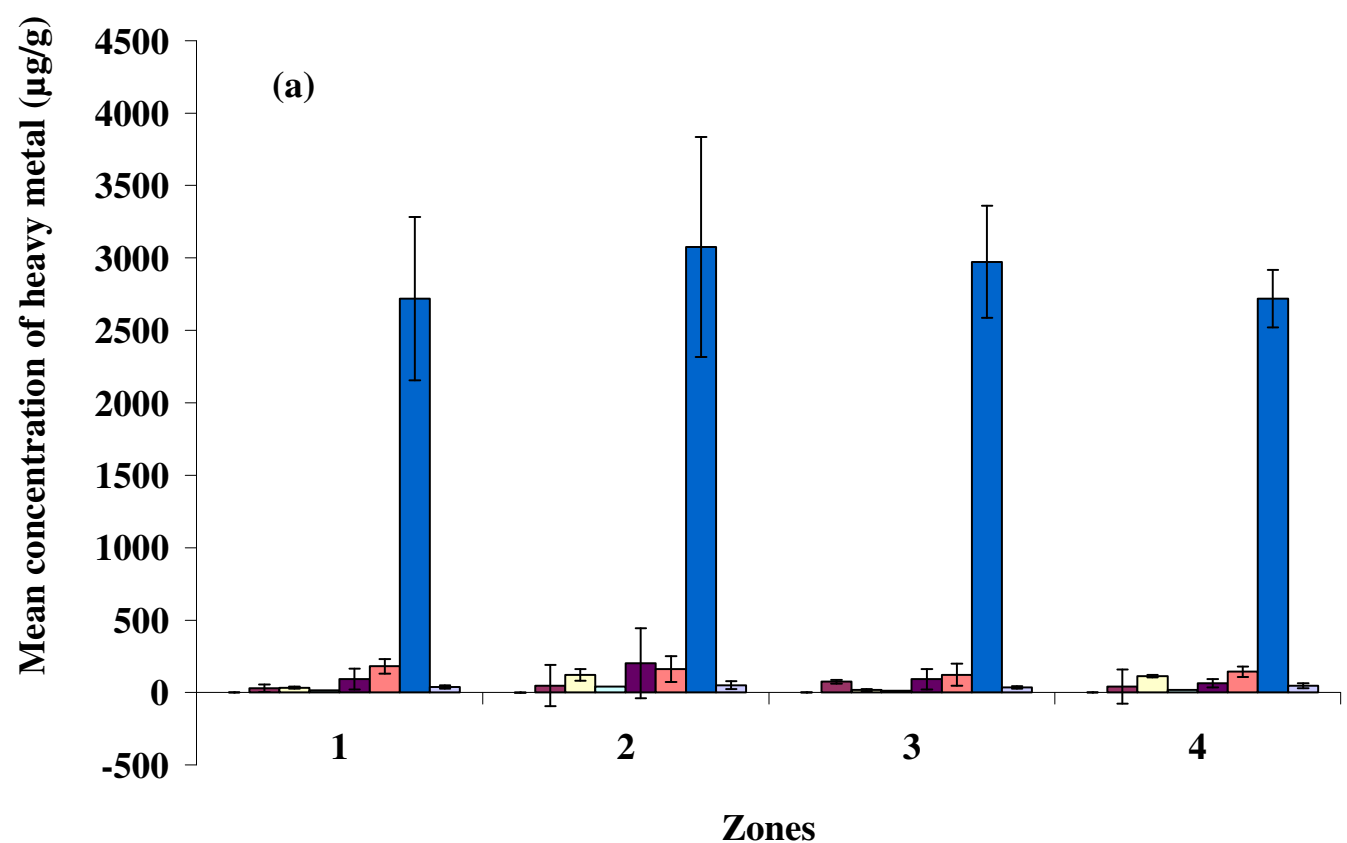

Fig. 2a: Distribution of heavy metals in settled particles (dust) collected from indoor of different zones in 2007

In 2008 (fig. 2b) high Cd level was detected in zone $1 \quad\left(1.29 \mathrm{\mu gg}^{-1}\right)$ significantly $(\mathrm{P}<0.05)$ different from zones 2 and 3 but lowest in zone $3(0.29$ $\left.\mu \mathrm{gg}^{-1}\right)$. The highest and lowest level of $\mathrm{Cr}$ were in zone $3\left(60.73 \mu^{-1}\right)$ and zone 1 $\left(8.86 \mathrm{\mu gg}^{-1}\right)$ respectively significantly $(\mathrm{P}<0.05)$ different from the other zones. $\mathrm{Cu}$ level was highest in zone 2 (58.64 $\mu g g-1)$ significantly $(\mathrm{P}<0.05)$ different from the other zones but lowest in zone 4 $\left(10.40 \mu \mathrm{gg}^{-1}\right)$ not significantly $(\mathrm{P}>0.05)$ different from zone 3 . Ni level was highest in zone $4 \quad\left(18.74 \mu \mathrm{gg}^{-1}\right)$ significantly $(\mathrm{P}<0.05)$ different from the other zones but lowest in zone 2 (3.61 $\mu \mathrm{gg}^{-1}$ ) not significantly ( $\left.\mathrm{P}>0.05\right)$ different from zone 1 and 3 . The highest $\mathrm{Pb}$ level was in zone $3\left(48.69 \mu \mathrm{gg}^{-1}\right)$ not significantly $(\mathrm{P}>0.05)$ different from zone 2 and 4 but significantly $(\mathrm{P}<0.05)$ different from zone $1\left(13.62 \mu \mathrm{gg}^{-1}\right)$ which had the lowest level. Zn level was highest in zone $3\left(227.56{\mu g^{-1}}^{-1}\right)$ significantly $(\mathrm{P}<0.05)$ different from the other zones but lowest in zone $1\left(138.13 \mu \mathrm{gg}^{-1}\right)$. Fe level was highest in zone $2\left(3076.01 \mu \mathrm{gg}^{-}\right.$ $\left.{ }^{1}\right)$ which was significantly $(\mathrm{P}<0.05)$ different from other zones but lowest in zone $4\left(2719.19 \mu \mathrm{gg}^{-1}\right)$. Highest level of Mn was highest in zone $3\left(116.63 \mu \mathrm{gg}^{-1}\right)$ significantly $(\mathrm{P}<0.05)$ different from the other zones but lowest in zone 1 (88.12 $\left.\mu \mathrm{gg}^{-1}\right)$. The order heavy metals prevalence indoor in 2008, was $\mathrm{Fe}>\mathrm{Zn}>\mathrm{Mn}>\mathrm{Pb}>\mathrm{Cr}>\mathrm{Cu}>\mathrm{Ni}>\mathrm{Cd}$ while the mean occurrence across the zones was: zone $2>3>4>1$ (Fig. 2b). Furthermore, there was drastic reduction in the concentrations of $\mathrm{Cd}, \mathrm{Cr}, \mathrm{Cu}, \mathrm{Pb}$ and $\mathrm{Fe}$ in 2008 whereas $\mathrm{Zn}$ and $\mathrm{Mn}$ concentrations increased in 2008 compared to 2007. 
Occurrence and Distribution of Heavy Metals in Indoor Settled Particles.................OSUALA et al.

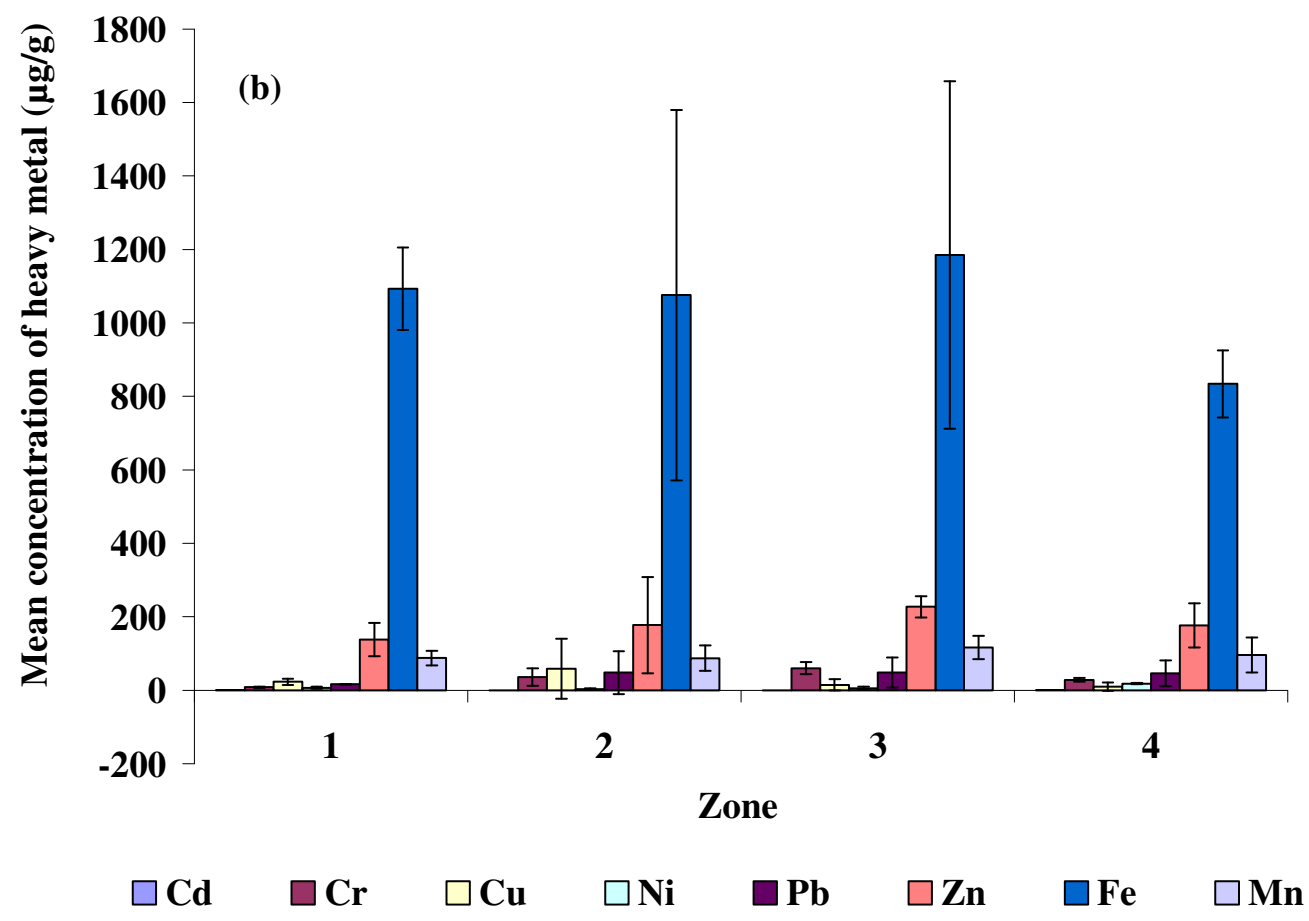

Fig. 2b: Distribution of heavy metals in settled particles (dust) collected from indoor of different zones in 2008

\section{Discussion}

The present study has established the occurrence and abundance of various heavy metals such as $\mathrm{Cd}, \mathrm{Cr}, \mathrm{Cu}, \mathrm{Fe}, \mathrm{Mn}$, $\mathrm{Ni}, \mathrm{Pb}$ and $\mathrm{Zn}$ detected in settled particles (dust) collected from indoor areas of designated zones of the Lagos metropolis, between 2007 and 2008 field survey. This is in agreement with the findings of Otitoloju and Don-Pedro (2002 and 2004, Norhayati et al. (2007) and Anna et al. (2008). Higher levels of heavy metals occurrence and variation indoor compared to outdoor corroborates with the findings of Abdul-Wahaba and Yaghib (2006), Gemenetzis et al. (2006), Manno et al. (2006). This could probably be due to dust infiltration from outdoor which stick to particles, other materials and make their way indoor. Additionally, the wide spread of heavy metals contamination in the environment were in agreement with Norhayati et al. (2007); Shinggu et al. (2007). However previous research has shown the occurrence of elevated concentrations of $\mathrm{Zn}(2012 \mathrm{mg}$ $\left.\mathrm{kg}^{-1}\right), \mathrm{Pb}\left(101.88 \mathrm{mg} \mathrm{kg}^{-1}\right)$ and $\mathrm{Cd}$ $\left(28.38 \mathrm{mg} \mathrm{kg}^{-1}\right)$ in elementary schools environs in Mexico (Diana et al., 2007).

The high level of indoor Cd observed in zone 2 during the 2007 sampling period could be from sources such as carpet wear, galvanized iron roofs and red/orange/yellow coloured carpets which were present at sampled sites while the lowest $\mathrm{Cd}$ level observed in zones 3 could probably be attributed to increased distance from point pollution, this is in agreement with the findings of Tong and Lang (1998); Adekola and Dosumu (2001). 
The elevated $\mathrm{Zn}$ level in zone 1 could be attributed to the sites of samples which were close to the road with high traffic load, corrosion of galvanized automobile parts as well as the wear and tear of tyres. Dust from tyres is a significant source of zinc in the urban environment. The other sources of $\mathrm{Zn}$ indoor could have been generated from products made from rubber, fillers in linoleum and paints (Al-Khashman, 2004; Nor et al., 2012) and galvanized iron roofs. Elevated level of $\mathrm{Cu}$ could probably be due to intrusion from the external surroundings as a result of high traffic movement that was experienced in zone 2 (a sample site located in UNILAG campus). Another probable contributive source could be from vacuum cleaners employed in interior cleaning and fan.

The highest $\mathrm{Ni}$ level in zone 2 corroborates with the research of Nor et al. (2012) on Ni levels (1.50 to 32.70 $\mathrm{mgkg}^{-1}$ ) in residential building. A probable source could be emission from automobile, brake dust, bearing metals and fallout from paint walls (Adekola and Dosumu, 2001).

The highest level of $\mathrm{Pb}$ in zone 2, may probably be due to the house age with leaded paint interior and the ability of the deteriorated walls of the interior, windows, distorted doors, carpets and crevices in floor to trap heavy metals like $\mathrm{Pb}$ (Lindern et al., 2003; Rasmussen et al., 2011). Mn detected in zone 2 could have originated from infiltration of outdoor air, smoking, indoor cooking and activities such as cleaning, dusting, and vacuuming. In terms of prominence, lowest $\mathrm{Cd}$ level from all zones was consistent with findings of Adekola and Dosumu (2001) on heavy metal determination in household dust from
Ilorin city in Nigeria. However, Mohamed (2008) recorded the prevalence of heavy metal in outdoor fallen dust in Aswan city as $\mathrm{Fe}>\mathrm{Mn}>\mathrm{Pb}>\mathrm{Cd}$. Furthermore, the elevated level of $\mathrm{Cd}$ in zone 1 in 2008 indoor compared to 2007 could probably be an indication of increased $\mathrm{Cd}$ transport from outdoor to indoor. This could also have been generated from anthropogenic activities such as cooking with coal that is a common practice in the sampled zone because of its availability and affordability. Overall, elevated $\mathrm{Cd}$ concentrations indoor dust has been reported by Matthew et al. (2012) in La Oroya Antigua. The elevated $\mathrm{Cu}$ level in zone 2 could be attributed to dusty carpets, proximity to road and road traffic (Madany and Crump, 1993). The highest concentration of $\mathrm{Ni}$ and $\mathrm{Cr}$ could be attributed to outdoor dust, the use of $\mathrm{Cr}$ and $\mathrm{Ni}$ plated household products and tobacco smoke that is highly probable if anyone of the occupants smoke tobacco.

The elevated indoor $\mathrm{Pb}$ detected was not surprising because most of the samples were collected from smoking homes and the interior was painted with leaded paints (Morawska and Salthammer, 2003). Moreover, $\mathrm{Pb}$ is a common pollutant in urban areas due to automobile emission (Chattopadhyay et al., 2003).

The detection of $\mathrm{Zn}$ in higher levels in zone 3 is in agreement with the findings of Rasmussen et al. (2001). This could be explained based on infiltrations of outdoor pollutants such as automobiles, lubricating oil or the burning of incense to dispel insects, rubber carpets underlay and smoking (Morawska and Salthammer, 2003). Elevated concentrations of $\mathrm{Fe}$ and $\mathrm{Mn}$ 
Occurrence and Distribution of Heavy Metals in Indoor Settled Particles.................OSUALA et al.

observed indoors in zone 2 and 3 respectively have also been reported by Zacco et al. (2009) and Yang (2012). According to Tong and Lang (1998) indoor dust is one of the major pathways of childhood exposure to heavy metals. This study revealed the importance of settled particles (dust) as one of the important sources of heavy metals exposure to man and therefore justify the emphasis in this study for evaluation of occurrence and distribution of heavy metals in places where people spend considerable period of time.

Additionally the high concentration of Fe detected indoor in 2008 irrespective of the sampled zones probably suggests that the area could have similar Fe inputs since most of the sampled sites were near road side. The detection of $\mathrm{Fe}$ in indoor dust has been reported by Rasmussen et al. (2001). Furthermore, the drastic reduction in the concentrations of $\mathrm{Cd}, \mathrm{Cr}$, $\mathrm{Cu}, \mathrm{Pb}$ and $\mathrm{Fe}$ in 2008 might have resulted from climatic alterations that could have contributed to decreased concentrations of these metals contrary to the increased concentrations of $\mathrm{Zn}$ and $\mathrm{Mn}$ concentrations in 2008 when compared to 2007.

The detection of significantly high concentrations of varied heavy metals in all the sampled zones implied that settled particles (dust) is a complex mixture of multiple source contributions which includes; anthropogenic materials such as automobile / truck exhaust particles, lubricating oil residues, tirewear particles, weathered street surface particles, brake lining wear particles, and natural biogenic materials such as leaves and other plant matter that can be pulverized by the passing traffic or exhaust emissions (Nasr et al., 2003 and Emanuela et al., 2006).

Suspended particle matter in air and its deposition in dwelling places is one of the fastest growing types of environmental pollution. The fallout of atmospheric particles is an important factor when considering the fate and effects of heavy metal pollution on human health. The toxicological risks of heavy metals that are associated with settled particles that are potentially inhaled by humans have much uncertainty, mainly due to poor knowledge and awareness. Therefore, it is important to provide baseline information on heavy metals concentrations in settled particles for future environmental monitoring studies in selected areas of Lagos metropolis.

\section{Conclusion}

The implication of this monitoring study and those of similar studies mentioned earlier have now provided a fair amount of basic environmental data, on the heavy metals levels indoor dust within the designated areas of the Lagos metropolis re - emphasizing the importance of metal sources such as settled particles in the overall exposure routes around living dwellings. Further studies will be carried out to monitor the present levels of these heavy metals in the selected areas.

\section{Acknowledgments}

The authors would like to acknowledge the Chemistry Department of University of Lagos for providing a laboratory space for analyzing the samples used for this research 


\section{References}

Abdul, R.A. (2011). Policy of Sustainable Environment: Malaysian Experience. European Journal of Scientific Research, 48(3): 466-492.

Abdul-Wahaba, S.A. and Yaghib, B. (2006). Total Suspended Dust and Heavy Metal Concentrations Emitted from Work Place Compared with Near by Residential Houses. Atmospheric Environment, 38(5): 745-750.

Adriano, D.C. (2001). Trace Elements in Terrestrial Environments:

Biogeochemistry Bioavailability and Risk of Metals. $2^{\text {nd }}$ edition, Springer - Verlag, New-York.866 pp.

Agemian, H. and Chau, A.S.Y. (1976). Evaluation of Extraction Techniques for the Determination of Metals in Aquatic Sediments. ANALYST 101:761-767.

Al-Damluji, S.F. (1976). Organomercury Poisoning in Iraq: History Prior to the 1971-72 Outbreaks. Bulletin of the World Health Organization, 53: 9-13.

Al- Khashman, O.A. (2004). Heavy Metal in Dust, Street Dust and Soils from the Work Place in Karak Industrial Estate, Jordan. Atmospheric Environment, 38: 6803-6812.

Anna, O.W., Nurdan, S.D., Cheung, K.C. and Ming, H.W. (2008). Heavy Metal Concentration of Surface Dust from e-Waste Recycling and its Human Health Implications in Southeast China. Environmental Science and Technology, 42(7): 2674-2680.
Bryan, G.W. and Langston, W.J. (1992). Bioavailability, Accumulation and Effects of Heavy Metals in Sediments and Special Reference to United Kingdom Estuaries: A Review. Environmental Pollution, 76(2): 89-131.

Chattopadhyay, G., Lin, K.C. and Feitz, A.J. (2003). Household Dust Metal Concentration in Sydney Metropolitan Area. Environmental Research, 93: 301-307.

Chin, W. T., Kok, H.T., Yit, T.O., Abdul, R. M., Sharif, H.S. and Soon, H.T. (2012). Carbon Nanotubes Applications: Solar and Fuel Cells, Hydrogen Storage, Lithium Batteries, Supercapacitors, Nanocomposites, Gas, Pathogens, Dyes, Heavy Metals and Pesticides. Environmental Chemistry for a Sustainable World, 1(1): 3-46.

Chukwu, L.D. (1991). Studies of Heavy Metal Contamination of Water, Sediment and Decapods Crustaceans from River Sasa. Ph.D Thesis, University of Lagos. 164pp.

Dan'Azumi, S. and Bichi, M.H. (2010). Industrial Pollution and Heavy Metals Profile of Challawa River in Kano, Nigeria. Journal of Applied Sciences in Environmental Sanitation, 5(1): 23-29.

Devagi, K., and Arfiziah, A. (2009). Accumulation and Depuration of Lead and Chromium Using Nerita Lineate. World Applied Science Journal, 6(9): 1205-1208.

Diana, M., Magarita, D. and Maria, L. (2007). Heavy Metal Distribution in Dust from Elementary Schools in Hermosillo, Sonora, Mexico. Atmospheric environment, 41(2): 276-288. 
Emanuela, M., Daniela, V. and Gaetano, D. (2006). Metal Distribution in Road Dust Samples Collected in an Urban Area Close to a Petrochemical Plant at Gela, Sicily. Atmospheric Environment, 40(30): $5929-5941$.

Falusi, B.A. and Olanipekun, E.O. (2007). Bioconcentration Factors of Heavy Metals in Tropical Crab (Carcinus Sp) from River Aponwe, Ado-Ekiti, Nigeria. Journal of Applied Sciences and Environmental Management, 11(4): 51-54.

Gary, J.M., Philip, W.D. and Bernard, W. (2007). Methyl mercury Exposure and Poisoning at Niigata, Japan. Seychelles Medical and Dental Journal, 7(1): 321-322.

Gemenetzis, P., Moussas, P., Arditsoglou, A. and Samara, C. (2006). Mass Concentration and Elemental Composition of Indoor PM 2.5 and PM 10 in the University Rooms in Thessaloniki, Northern Greece, Atmospheric Environment, 40(17): 3195-3206.

Jun-ichi, M. (2006). Itai - itai byo no kioku (new Edition). Toyama : Katsura Shobo. Pp 7-8.

Kan, U., Koichi, K., Keiko, O., Shin, N., Yumiko, S., Yasuhiro, K., Akihiro, K., Yuko, T., Motoshi, K. and Yasuhisa, Y. (2011). Toxicological Aspects of Cadmium and Occupational Health Activities to Prevent Workplace Exposure in Japan. A Narrative Review, 27(3): 225-233.

Kurland, L. (1960). Minamata Disease. World Neurology, 1: 370.

Lindern, I.H., Spalinger, S.M., Bero, B.N., Petrosyan V. and Braun, M.C.
(2003).The Effect of Soil Remediation on Lead in House Dust. Science of the Total Environment, 303: 59-78.

Madany, I.M., Akhter, M.S. and Aljowder, O.A. (1994). The Correlations between Heavy Metals in Residential Indoor Dust and Outdoor Street Dust in Bahrain. Environment International, 20: 483-492.

Manno, E., Varrica, D. and Dongarra, G. (2006). Metal Distribution in Road Dust Samples Collected in an Urban Area Close to a Petrochemical Plant at Gela, Sicily, Italy. Atmospheric Environment, 40: 5929-5941.

Marcovecchio, J.E., Botte, S.E. and Freije, R.H. (2007). Heavy metals, Major Metals, Trace Elements. In: Handbook of Water Analysis L.M. Noiiet, (Edition). $2^{\text {nd }}$ Edition. London: CRC Press. Pp 275-311.

Matthew, J.J., Amy, H.R., Kevin, S., Gregory, W.W. and Robert, W.C. (2004). Diversity of Metallothioneins in the American Oyster, Mohamed, N.R. (2008). Total and Extractable Heavy Metals in Indoor Outdoor and Street Dust from Aswan City, Egypt. Clean, 36(10 - 11): $850-857$.

Mohamed, N.R. (2008). Total and Extractable Heavy Metals in Indoor, Outdoor and Street Dust from Aswan City, Egypt. Clean, 36 (10 - 11): 850 - 857.

Mohamed, R. and Elsayed, A.S. (2007). Dispersion and Dispersion of Heavy Metals around Two Municipal Solid Waste (MSW) Dumpsites, Alexandria, Egypt. American - Eurasian Journal of 
Agric \& Environmental Science, 2(3): 204-212.

Morawska, L. and Salthammer, T. (2003). Indoor environment: Airborne particles and settled dust. New York, NY: John Wiley \& Sons. 467 pp. ISBN 3527305254

Nasr, Y.M., Omar, M.R., Noorsaadah, A.R., Norhayati, M.T., Ahmed, I.R. and Bernd R.T. (2003). Concentrationsand Distributions of Organic Source Tracers in Air and Roadside Dust Particles of Kuala Lumpur, Malaysia. Environmental Geology, 52(8): 1485-1500.

Nor, A. A. W., Fairus, M.D., Norain, I., Siti, M.S. and Nur Fatihah, M.H (2012). Heavy Metal Concentration of Settled Surface Dust in Residential Building. The Malaysia Journal of Analytical Sciences. 16(1): 18-23.

Norhayati, M.T., Poh, S.C. and Maisarah, J. (2007). Determination of Heavy Metals Content in Soiland Indoor Dusts from Nurseries in Dungan, Terengganu. The Malaysian Journal of Analytical Sciences, 11(1): 280-286.

Otitoloju, A.A. and Don-Pedro, K.N. (2002). Bioaccumulation of Heavy Metals ( $\mathrm{Zn}, \mathrm{Pb}, \mathrm{Cu}$ and $\mathrm{Cd}$ ) by Tympanotonus fuscatus var. radula (L) exposed to sublethal Concentrations of the Test metal Compounds in Laboratory Bioassay.West African Journal of Applied Ecology, 3: 17-29.

Otitoloju, A.A. and Don-Pedro, K. N. (2004). Integrated Laboratory and Field Assessments of Heavy Metals Accumulation in Edible Periwinkle, Tympanotonus fuscatus var. radula (L). Ecotoxicology and
Environmental Safety, 57(3): 354362.

Rasmussen, P. E., Subramanian, K. S. and Jessiman, B. J. (2001). A Multi-Element Profile of House Dust in Relation to Exterior Dust and Soils in the City of Ottawa, Canada. Science of the Total Environment, 267: 125-140.

Rasmussen, P.E., Beauchemin, S., Chénier, M., Levesque, C., MacLean, L.C.W., Marro, L., Jones-Otazo, H., Petrovic, S., McDonald, L.T. and Gardner, H.D. (2011). Canadian House Dust Study: Lead Bioaccessibility and Speciation. Environmental Science and Technology, 45(11): 49594965 .

Sham, K.W., Tasneem, G.K., Nida, F.K., Hassan, I.A., Sumaira, K., Akhtar, A.C., Abdul, Q.S., Ghulam, A.K. and Syeda, N. (2011). Case-Control Study of Male Cancer Patients Exposed to Arsenic-Contaminated Drinking Water and Tobacco Smoke with Relation to NonExposed Cancer Patients. Human and Experimental Toxicology doi: 10.1177/0960327111408154.

Shinggu, D.Y., Ogugbuaja, V.O., Toma, I. and Barminas, J.T. (2007). Determination of Heavy Metal Pollutants in Street Dust of Yola, Adamawa State, Nigeria. African Journal of Pure and Applied Chemistry, 4(1): 017-021.

Shinggu, D.Y., Ogugbuaja, V.O., Toma, I., Barminas J.T. and Toma, I. (2007). Analysis of Street Dust for Heavy Metal Pollutants in Mubi, Adamawa State, Nigeria. International Journal of Physical Science, 2(11): 290-293. 
Occurrence and Distribution of Heavy Metals in Indoor Settled Particles.................0SUALA et al.

Tong, S.T. and Lang, K.C. (1998). Are Nursery Schools and Kindergartens Safe For Our Kids? (The Hong Kong Study). Science Total Environment, 216(3): 217-225.

Yang, J. (2012). Elemental Analysis in House Dust Using Handheld XRay Flouorescence. Ph.D Thesis. 62pp.
Zacco, A., Resola, S., Lucchini, R., Albini, E., Zimmerman, N., Guazzetti, S. and Bontempi, E. (2009). Analysis of settled dust with X-ray fluorescence for exposure assessment of metals in the province of Brescia, Italy. Journal of Environmental Monitoring, 11(9): 1579-1585. 